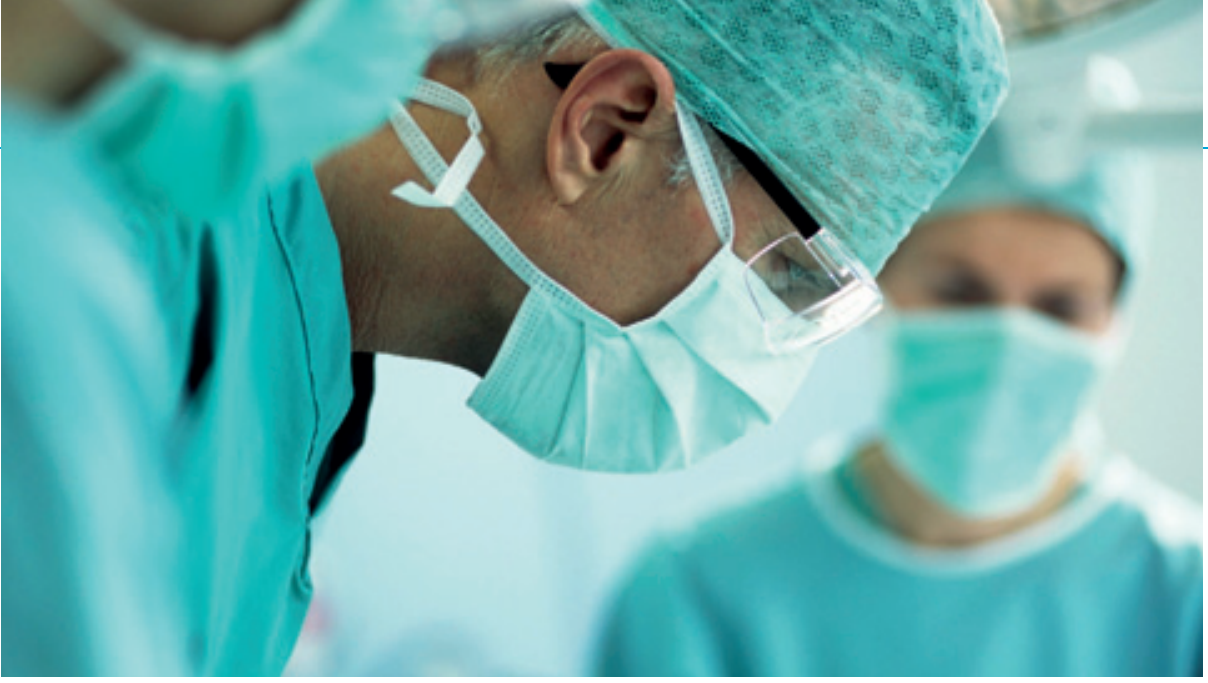

\title{
Dårlig fysisk form innvirker på livskvaliteten etter kirurgi
}

\author{
Dårlig preoperativ fysisk form er for- \\ bundet med suboptimal helserelatert \\ livskvalitet etter et kirurgisk inngrep \\ ifølge en ny studie.
}

Den prospektive kohortstudien omfattet 401 pasienter som gjennomgikk diverse elektive kirurgiske prosedyrer (1). De fylte ut et spørreskjema om helserelatert livskvalitet før operasjonen og seks og 12 måneder etter. Det ble gjort en preoperativ psykologisk vurdering.

De fleste merket bedring vedrørende alle aspekter av helserelatert livskvalitet etter inngrepet, men 12 måneder etterpå anga ca. $15 \%$ at de hadde mer smerte, lavere fysisk yteevne og flere emosjonelle problemer. $24 \%$ mente de var blitt mindre vitale enn de var før operasjonen.

De viktigste prediktorene for langvarig smerte og fysisk yteevne var akutt postoperativ smerte, operasjonsvarighet og pre- operativ fysisk form. Langtidsresultatet var dessuten influert av komorbiditet. Preoperativ frykt for inngrepet utgjorde også et lite, men signifikant bidrag. De viktigste prediktorene for mental helse og vitalitet var fysisk form før operasjonene, frykt for inngrepet og optimisme.

- Resultatene stemmer overens med tidligere studier. Mange ble ekskludert fra studien, og dette kan ha påvirket resultatet. Årsakssammenhenger er ikke nødvendigvis påvist $\mathrm{i}$ en epidemiologisk studie av denne typen, sier Gitte Handberg ved Tværfaglig Smerteklinik, Odense Universitetshospital, til Ugeskrift for Laeger.

Erlend Hem
erlend.hem@medisin.uio.no
Tidsskriftet
Litteratur
1. Peters ML, Sommer M, van Kleef M et al. Predic-
$\quad$ tors of physical and emotional recovery 6 and 12
$\quad$ months after surgery. Br J Surg 2010; 97 :
$\quad$ 1518-27.

\section{Erlend Hem}

erlend.hem@medisin.uio.no $518-27$

\section{Positiv effekt av screening for hørselstap hos nyfødte}

Hørselsscreening av nyfødte er assosiert med gunstigere utvikling - mindre bruk av tegnspråk og bedre overordnet sosial og grovmotorisk utvikling hos de hørselshemmede når de er 3-5 år gamle - enn screening når barna er eldre (JAMA 2010; 304: 1701-8).

I studieperioden ble det født 335000 barn i en region i Nederland hvor det var tilbud om nyfødtscreening, og det ble gjort en såkalt BOEL-test hos 234 000. Ved evalueringen i 2009 hadde 263 barn i gruppen som var blitt screenet som nyfødte, fått diagnostisert permanent hørselstap $10,78 / 1$ 000 barn). I BOEL-gruppen var det 171 barn (0,73/1 000). De som var blitt screenet som nyfødte, hadde signifikant bedre utviklingsferdigheter enn barna som ble undersøkt med BOEL-testen.

\section{Akamprosat til behandling av alkoholisme}

Adjuvant behandling med akamprosat kan være effektivt og sikkert som støtte ved alkoholabstinens, ifølge en ny Cochraneoversikt (Cochrane Database Syst Rev 2010; nr. 9: CD004332). Akamprosat er en glutamatantagonist som påvirker hjernens eksitatoriske nevrotransmisjon. Gjennom akamprosatbehandling er hensikten å oppnå et redusert alkoholinntak ved at trangen til alkohol blir redusert.

Forfatterne inkluderte 24 dobbeltblindede, randomiserte studier med i alt 6915 deltakere. Sammenliknet med placebo førte akamprosatbruk til et signifikant fall i risikoen for å drikke, med en relativ ratio på 0,86. Det var ikke noen signifikant effekt på stort alkoholinntak. Den moderate behandlingseffekten kan likevel være verdifull, mener forfatterne, sett i lys av alkoholismens residiverende natur og de

\section{Nytt antistoff gir økt overlevelse ved nevroblastom}

\section{For barn med nevroblastom er det høy risiko for tilbakefall etter høydose kjemoterapi. Tilleggsbehandling med et antistoff mot tumorgangliosidet GD-2 øker overlevelsen.}

Nevroblastom er kreft utgått fra det sympatiske nervesystem. Sykdommen er årsak til ca. $12 \%$ av kreftrelaterte dødsfall hos barn under 15 år (1). Pasienter med utbredt sykdom og god cellegiftrespons tilbys høydosebehandling med stamcellestøtte, men om lag halvparten vil få tilbakefall. Gangliosidmolekylet GD-2 er høyt uttrykt på overflaten av nevroblastomceller og samtidig lite uttrykt i normalvev.

I en ny studie med 226 pasienter har man sammenliknet standard konsolideringsterapi etter høydosebehandling (isotretinoin) med tillegg av immunterapi, $i$ form av et antistoff mot GD2 pluss cytokiner (1). Etter to års observasjonstid hadde gruppen som fikk immunterapi signifikant høyere residivfri overlevelse $(66 \%$ versus $46 \%)$ og totaloverlevelse $(86 \%$ versus $75 \%)$ enn kontrollgruppen.

- Nevroblastom er en meget interessant kreftform, sier overlege Finn Wesenberg ved Kompetansesenter for solide svulster hos barn, Oslo universitetssykehus. - Den kan gå spontant tilbake uten behandling i første leveår, men kan også være en høymalign sykdom senere i barneårene. Prognosen har vært dårlig. Internasjonale kliniske studier, der Norge har deltatt, har gitt høyere overlevelse ved den høymaligne varianten. Tradi- sjonell kreftterapi har likevel ikke gitt de ønskede resultater, og det er et sterkt ønske om mer målrettet behandling.

Studien viser at overlevelsen blir forbedret når man kombinerer intensiv cytostatikabehandling, A-vitamin, interleukin og målrettet antistoffbehandling. For å bekrefte disse lovende resultatene pågår det en tilsvarende europeisk studie der Norge deltar, sier Wesenberg.

\section{Jon Amund Kyte}

jon.amund.kyte@rr-research.no

Tidsskriftet

\section{Litteratur}

1. Yu AL, Gilman AL, Ozkaynak MF et al. Anti-GD2 antibody with GM-CSF, interleukin-2, and isotretinoin for neuroblastoma. N Engl J Med 2010; 363: 1324-34 